\title{
Study of Interferon- $\gamma$-Inducible Protein 10 (IP 10) Level as a Diagnostic and Prognostic Marker in Patients on Sofosbuvir and Daclatasvir as Antiviral Therapy of Chronic Hepatitis C.
}

Mostafa Yousef ELmishad ${ }^{1}$, Alsayed Ahmed Gouda ${ }^{1}$, Ali Saad Elden Nada ${ }^{2,}$ Ahmed Hussin Al-Dehna ${ }^{1}$.

${ }^{1}$ Department of Microbiology and Immunology, Faculty of Medicine, Al-Azhar University,

${ }^{2}$ Department of Hepatology, National Hepatology Institute Al- Menofia University

\begin{abstract}
Background: Hepatitis C virus (HCV) belongs to the family Flaviviridae. Elevated plasma levels of the interferon$\gamma$-inducible protein 10 (IP 10) is common in HCV infection.

Objective: study of IP 10 level as a diagnostic and prognostic marker in patients on sofosbuvir and daclatasvir as antiviral therapy of chronic HCV in comparison with HCV RNA level estimated by PCR.

Patients and methods: ELISA estimation of IP 10 serum level and quantitative PCR for hepatitis C RNA virus done for 40 chronic $\mathrm{HCV}$ patient before, within and after undergoing antiviral therapy in the form of Sofosbuvir and Daclatasvir \pm Ribavirin. In addition, ELISA estimation of IP 10 serum level was done to 20 apparently healthy individuals as a control group.

Results: IP 10 serum concentrations were significantly higher in patients than in control group. Sofosbuvir and daclatasvir significantly decreased IP 10 serum level concentrations and this change in concentrations was statistically highly significant. HCV PCR mean were $39 \times 10^{4} \pm 78 \times 10^{4} \log \mathrm{IU} / \mathrm{ml}$ ) before start of treatment then declined to undetectable level after one month of treatment till 3 months after the end of treatment. This change in concentrations was statistically significant.

Conclusions: IP 10 may be used as a prognostic but not diagnostic marker for treatment efficacy in chronic HCV infected patients subjected to sofosbuvir/daclatasvir combination therapy.

Keywords: Interferon- $\gamma$-Inducible Protein 10, IP 10, Chronic Hepatitis C, direct acting antiviral therapy, Sofosbuvir, Daclatasvir.
\end{abstract}

Abbreviation:

DAAT: Direct acting antiviral therapy, ELISA: enzyme linked immunosorbent assay, HBV: Hepatitis B virus, HCV: hepatitis C virus, IP 10: interferon- $\gamma$-inducible protein 10, NK: natural killer, PCR: Polymerase chain reaction, RNA: Ribonucleic acid, SVR: sustained virological response, Th: T helper.

\section{INTRODUCTION}

The hepatitis $\mathrm{C}$ virus (HCV) belongs to the family Flaviviridae, these viruses are structurally similar and contain positive single-stranded RNA surrounded by a protective lipid bilayer. The Flaviviridae family is divided into three genera, Flavivirus, Pestivirus, and Hepacivirus where the hepatitis $\mathrm{C}$ virus (HCV) is included ${ }^{(1)}$.

In Egypt $15 \%$ of an estimated population are $\mathrm{HCV}$ positive, $93 \%$ of $\mathrm{HCV}$-infected individuals are infected with genotype 4, which includes 17 confirmed subtypes, which cause approximately $13 \%$ of infections worldwide, with prevalence varying by geographic region ${ }^{(2)}$.

Elevated plasma levels of the interferon- $\gamma$-inducible protein 10 (IP- 10) is common in HCV infection. IP10 is a chemokine produced by endothelial cells, activated $\mathrm{T}$ cells and hepatocytes during $\mathrm{HCV}$ infection, exerting its effects mainly through a $G$ protein-coupled receptor CXCR3. IP-10 signaling through CXCR3 induces different effects depending on the site of receptor binding. One central effect of IP-10 is trafficking of activated, IFN- $\gamma$ producing NK cells, $\mathrm{T}$ cells and monocytes to the site of infection, promoting a TH1 response ${ }^{(3)}$. The IP-10 levels were positively correlated with the extent of organ damage and pathogen burden. In both HCV-monoinfected and HCV/HIV coinfected patients, elevated IP 10 levels were positively correlated with liver damage (as indicated by high liver fibrosis scores and liver enzyme levels) ${ }^{(4)}$.

Several studies have reported that IP-10 may be a prognostic marker for $\mathrm{HCV}$ treatment efficacy in $\mathrm{HCV}$ infection. Elevated pretreatment serum IP-10 concentrations correlate with non-response to PegIFN/RBV therapy ${ }^{(5)}$.

Sofosbuvir/daclatasvir combination is associated with a high rate of SVR in genotype 1 or 4 patients who are assumed to be difficult to treat. Adding Ribavirin increases the SVR rate in treatmentexperienced and cirrhotic patients ${ }^{(6)}$.

\section{AIM OF THE WORK}

The study of IP 10 level as a diagnostic and prognostic marker in patients on sofosbuvir and daclatasvir as antiviral therapy of chronic $\mathrm{HCV}$ in comparison with HCV RNA level estimated by PCR.

\section{PATIENTS AND METHODS}

This study was carried out in Al-Araby International Hospital during the period between January 2018 to March 2019 on 40 patients diagnosed 
as chronic hepatitis $\mathrm{C}$ virus $(\mathrm{HCV})$ with or without cirrhosis undergoing direct acting antiviral therapy in the form of oral sofosbuvir and daclatasvir \pm ribavirin for 3 months and 20 apparently healthy individuals as a control group. Informed consent was taken from both patient and control groups before starting the study.

\section{Ethical approval and written informed consent: An approval of the study was obtained from Al- Azhar University Academic and Ethical Committee.}

Every patient signed an informed written consent for acceptance to share in the study.

Exclusion criteria: Patients with organ transplantation, hepatocellular carcinoma, HBS Ag positive, diabetic patients and conditions known to be associated with elevated serum IP 10 as inflammatory bowel disease and rheumatoid arthritis were excluded.

Patients' group were 40 patients diagnosed as chronic hepatitis $\mathrm{C}$ virus (HCV). They were 30 males and 10 females. There ages ranged from 24 to 73 years old with mean of $43.95 \pm 13.72$. They were classified into 2 subgroups according to hepatic echogenic pattern (27 patients without cirrhosis 13 patients with cirrhosis). Control group were 20 apparently healthy individuals included 11 males and 9 females. There ages ranged from 24 to 60 years old with mean of $40.20 \pm 8.64$

All patients were subjected to proper history taking, complete medical examination and laboratory and radiological investigation as follows: Viral hepatitis markers (HCV antibodies), liver and kidney functions, complete blood count, quantitative PCR for hepatitis C virus RNA that was done for each patient 4 times; first PCR before beginning of treatment to confirm diagnosis, second PCR after 1 month of treatment, the third done at the end of therapy and the fourth one done 3 months after the end of therapy. Serum level of IP 10 by ELISA done 4 times for each patient; baseline sample before beginning of treatment, second sample after 1 month of treatment, the third done at the end of therapy and the fourth one done 3 months after the end of therapy. Control group was subjected to proper history taking, complete medical examination and laboratory investigations as follows: Viral hepatitis markers (HBS Ag, HCV antibodies) and serum level of IP 10 once by ELISA. Quantification of IP 10 serum levels was done in serology unit in the laboratory of Al-Araby International Hospital. Collection of blood samples was done by withdrawing of $3 \mathrm{ml}$ venous blood under aseptic condition from every patient on gel vacutainer tubes 4 times then tubes were centrifuged at $3000 \mathrm{rpm}$ for 5 minutes. The serum samples were transferred into Eppendorf tubes and stored at $-80^{\circ} \mathrm{C}$, then used for of IP 10 quantification. Repeated thawing and freezing were avoided. IP 10 serum levels were measured by enzyme linked immunosorbent assay according to the manufacturer's instructions using Glory Human Interferon-induced protein 10(IP-10) ELISA Kit (Glory Science Co., Ltd Add: 2400 Veterans Blvd. Suite 16 - 101, Del Rio, TX 78840, USA). Quantification of PCR hepatitis C RNA was done in molecular biology unit in the laboratory of Al-Araby International Hospital on Real-time instruments Rotor-Gene 3000/Rotor-Gene 6000 (Corbett Research, Australia); iCycler iQ5 (Bio-Rad, USA); Mx3000 (Stratagene, USA) instrument using AmpliSens HCV-Monitor-FRT PCR kit (Federal Budget Institute of Science "Central Research Institute for Epidemiology" 3A Novogireevskaya Street Moscow 111123 Russia) according to the manufacturer's instructions while RNA extraction was done on Automated nucleic acid purification system (Model no: MagPurix 12S, Zintexts life science corporation, zhonghe dist., new Taipei city 235 Taiwan via Reagent cartridge, Zintexts life science corporation, Taiwan).

\section{Statistical analysis}

Recorded data were analyzed using the statistical package for social sciences, version 23.0 (SPSS Inc., Chicago, Illinois, USA). Quantitative data were expressed as mean \pm standard deviation (SD). Qualitative data were expressed as frequency and percentage. The following tests were done:

- Independent-samples t-test of significance was used when comparing between two means.

- Chi-square $\left(\mathrm{x}^{2}\right)$ test of significance was used in order to compare proportions between two qualitative parameters.

- The confidence interval was set to $95 \%$ and the margin of error accepted was set to 5\%. The p-value was considered significant as the following:

- Probability (P-value)

- P-value <0.05 was considered significant.

- P-value <0.001 was considered as highly significant.

- P-value $>0.05$ was considered insignificant. 


\section{RESULTS}

Table (1): Socio-demographic characteristics of studied groups

\begin{tabular}{|c|c|c|c|c|c|c|c|}
\hline \multirow{3}{*}{$\begin{array}{c}\text { Socio } \\
\text { demographic } \\
\text { data }\end{array}$} & \multicolumn{4}{|c|}{ Studied groups } & \multirow{3}{*}{$\begin{array}{c}\text { Test of } \\
\text { significance }\end{array}$} & \multirow{3}{*}{$\begin{array}{c}\mathbf{P} \\
\text { value }\end{array}$} & \multirow{3}{*}{ Sig } \\
\hline & \multicolumn{2}{|c|}{ Cases (40) } & \multicolumn{2}{|c|}{ Controls (20) } & & & \\
\hline & No. & $\%$ & No. & $\%$ & & & \\
\hline Age (years) & \multirow{2}{*}{\multicolumn{2}{|c|}{$\begin{array}{c}43.95 \pm 13.72 \\
24.00-73.00\end{array}$}} & \multirow{2}{*}{\multicolumn{2}{|c|}{$\begin{array}{l}40.95 \pm 9.67 \\
24.00-60.00\end{array}$}} & \multirow{2}{*}{$0.763^{*}$} & \multirow[b]{2}{*}{0.386} & \multirow[b]{2}{*}{ NS } \\
\hline Mean \pm SD & & & & & & & \\
\hline Gender & & & & & \multirow{3}{*}{$2.465^{\circ}$} & \multirow{3}{*}{0.102} & \multirow{3}{*}{ NS } \\
\hline Male & 30 & 75 & 11 & 55 & & & \\
\hline female & 10 & 25 & 9 & 45 & & & \\
\hline Residence & & & & & \multirow{3}{*}{$0.035^{\circ}$} & \multirow{3}{*}{0.534} & \multirow{3}{*}{ NS } \\
\hline Ruler & 25 & 62.5 & 12 & 60 & & & \\
\hline urban & 15 & 37.5 & 8 & 40 & & & \\
\hline Smoking & & & & & \multirow{3}{*}{$2.727^{\circ}$} & \multirow{3}{*}{0.120} & \multirow{3}{*}{ NS } \\
\hline Smoker & 5 & 12.5 & 0 & 0 & & & \\
\hline Not smoker & 35 & 87.5 & 20 & 100 & & & \\
\hline History of HTN & & & & & \multirow{3}{*}{$2.143^{\circ}$} & \multirow{3}{*}{0.187} & \multirow{3}{*}{ NS } \\
\hline Hypertensive & 4 & 10 & 0 & 0 & & & \\
\hline $\begin{array}{l}\text { Not } \\
\text { Hypertensive }\end{array}$ & 36 & 90 & 20 & 100 & & & \\
\hline History of IHD & & & & & \multirow{3}{*}{$2.727^{\circ}$} & \multirow{3}{*}{0.120} & \multirow{3}{*}{ NS } \\
\hline Ischemic & 5 & 12.5 & 0 & 0 & & & \\
\hline Not Ischemic & 35 & 87.5 & 20 & 100 & & & \\
\hline
\end{tabular}

* One-way anova • Chi-Square Test HTN: Hypertension IHD: Ischemic heart disease Sig.: Significance

Table (1) revealed that the mean age of HCV patients was $43.95 \pm 13.72$ years old and that of control group was $40.20 \pm 8.64$ years old with no significant difference. The study included $75 \%$ male patients and $25 \%$ female patients. There was no significant difference between cases and controls as regards co-morbidities like smoking, hypertension and ischemic heart disease $(\mathrm{P}$ value $<0.05)$. Also, there was no significant difference as regards residence.

Table (2): Comparison between studied groups cases and controls as regards pretreatment IP10 serum level.

\begin{tabular}{|c|c|c|c|c|c|}
\hline & \multicolumn{2}{|c|}{ Studied groups } & \multirow{2}{*}{$\begin{array}{c}\text { Test of significance } \\
\text { (ANOVA) }\end{array}$} & \multirow{2}{*}{$\begin{array}{c}P \\
\text { value }\end{array}$} & \multirow{2}{*}{ Significance } \\
\hline & Cases (40) & Controls (20) & & & \\
\hline $\mathrm{IP} 10(\mathrm{Pg} / \mathrm{ml})$ & & & \multirow{3}{*}{30.671} & \multirow{3}{*}{$\begin{array}{l}< \\
0.001\end{array}$} & \multirow{3}{*}{ HS } \\
\hline $\begin{array}{c}\text { Mean } \pm \text { SD } \\
\text { Range }\end{array}$ & $\begin{array}{c}176.97 \pm 73.70 \\
92-370\end{array}$ & $\begin{array}{c}84.85 \pm 10.55 \\
65-101\end{array}$ & & & \\
\hline Median & 149 & 85.5 & & & \\
\hline
\end{tabular}

Table (2) revealed that IP 10 serum concentrations (Figure1) were significantly higher in patients (mean $176.97 \pm$ $73.70 \mathrm{pg} / \mathrm{ml}$ ) than in control group (mean $84.85 \pm 10.55 \mathrm{pg} / \mathrm{ml}$ ). 


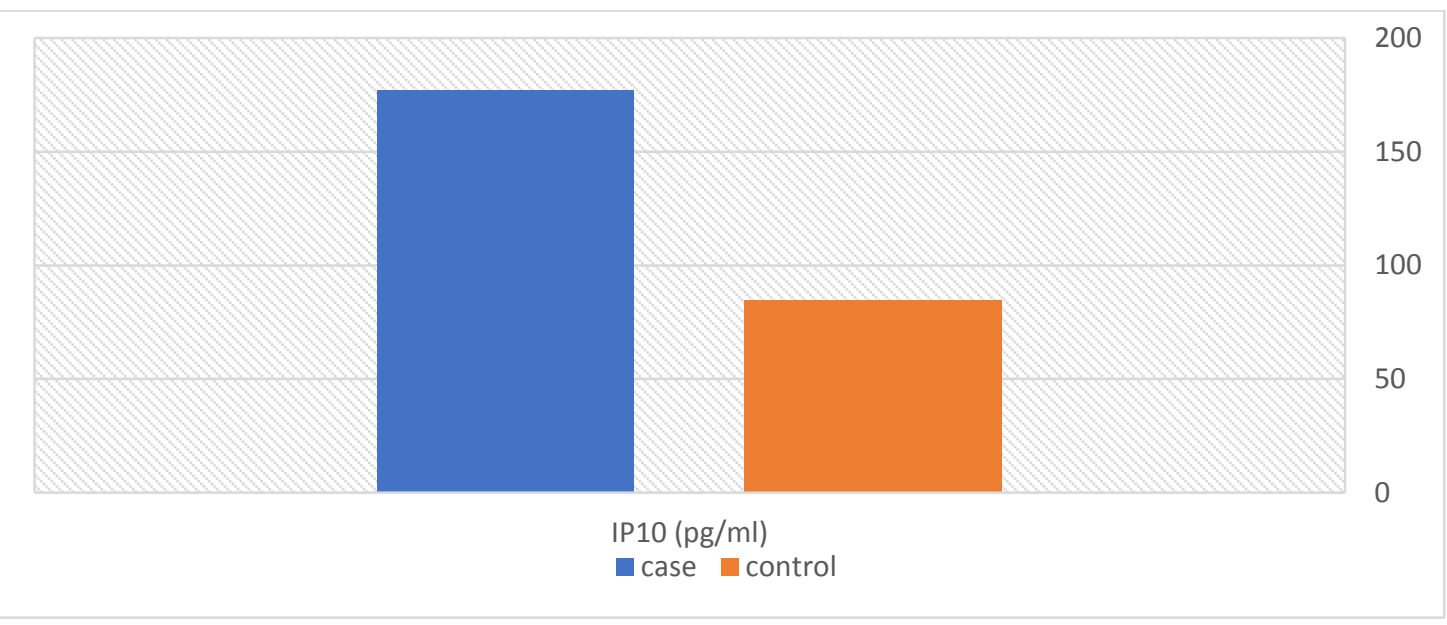

Figure (1): IP 10 serum concentrations in patients and controls groups

Table (3): Comparison between patients studied groups of cases as regard pretreatment IP10 serum level

\begin{tabular}{|l|c|c|c|c|c|c|}
\hline \multicolumn{2}{|c|}{$\begin{array}{l}\text { groups } \\
\text { Laboratients }\end{array}$} & $\begin{array}{c}\text { No cirrhosis } \\
\text { (NO.=27) }\end{array}$ & $\begin{array}{c}\text { Cirrhosis } \\
\text { (NO.=13) }\end{array}$ & $\begin{array}{c}\text { Test } \\
\text { value } \\
\text { ANOVA }\end{array}$ & $\begin{array}{c}\text { P- } \\
\text { value }\end{array}$ & Sig. \\
\hline \multirow{2}{*}{$\begin{array}{l}\text { IP10 } \\
(\mathrm{pg} / \mathrm{ml})\end{array}$} & Mean \pm SD & $156.96 \pm 64.07$ & $218.53 \pm 77.38$ & \multirow{2}{*}{7.079} & 0.01 & $\mathrm{~S}$ \\
\cline { 2 - 5 } & Range & $92-370$ & $142-366$ & 192 & & \\
\hline
\end{tabular}

Table (3) showed that there was significant correlation between pretreatment IP 10 serum level and the degree of cirrhosis. Cirrhotic patients' serum IP 10 concentrations level (mean $218.53 \pm 77.38$, median $192 \mathrm{pg} / \mathrm{ml}$ ) were higher than non-cirrhotic patients' serum IP 10 concentrations level (mean $156.96 \pm 64.07$, median 142 pg/ml) (P value < $0.05)$.

Table (4): Correlation between pretreatment IP 10 serum level and Hepatitis C viral load in the studied group of cases

\begin{tabular}{|c|c|c|c|}
\hline Laboratory parameters & Spearman correlation coefficient & P-value & Sig. \\
\hline HCV PCR & 0.137 & 0.39 & NS \\
\hline
\end{tabular}

Table (4) showed that HCV PCR level and IP 10 serum level concentrations were both high, but Spearman correlation coefficient was not statistically significant $(\mathrm{P}$ value $>0.05)$.

Table (5): Effect of treatment with sofosbuvir and daclatasvir on IP10 serum level after 1, 3 and 6 months among the studied groups of cases

\begin{tabular}{|c|c|c|c|c|c|c|c|}
\hline \multirow[b]{2}{*}{$\begin{array}{c}\text { IP10 } \\
(\mathbf{P g} / \mathrm{ml})\end{array}$} & \multicolumn{4}{|c|}{ Treatment } & \multirow[b]{2}{*}{$\begin{array}{c}\text { Multivariate } \\
\text { Tests }\end{array}$} & \multirow[b]{2}{*}{$\begin{array}{c}\text { P- } \\
\text { value }\end{array}$} & \multirow[b]{2}{*}{ Sig } \\
\hline & Pretreatment & After 1 month & $\begin{array}{l}\text { After } 3 \text { months } \\
\text { (at the end of } \\
\text { treatment) }\end{array}$ & $\begin{array}{l}\text { After } 6 \\
\text { months }\end{array}$ & & & \\
\hline $\begin{array}{c}\text { Mean } \pm \text { SD } \\
\text { Range }\end{array}$ & $\begin{array}{c}176.97 \pm 73.70 \\
92-370\end{array}$ & $\begin{array}{c}166.0 \pm 69.3 \\
89-350\end{array}$ & $\begin{array}{c}151.2 \pm 60.9 \\
75-330\end{array}$ & $\begin{array}{c}127.87 \pm 52.8 \\
62-290\end{array}$ & \multirow{2}{*}{29.57} & \multirow{2}{*}{$\begin{array}{c}< \\
0.001\end{array}$} & \multirow{2}{*}{ HS } \\
\hline Median & 149 & 138 & 129 & 110 & & & \\
\hline
\end{tabular}




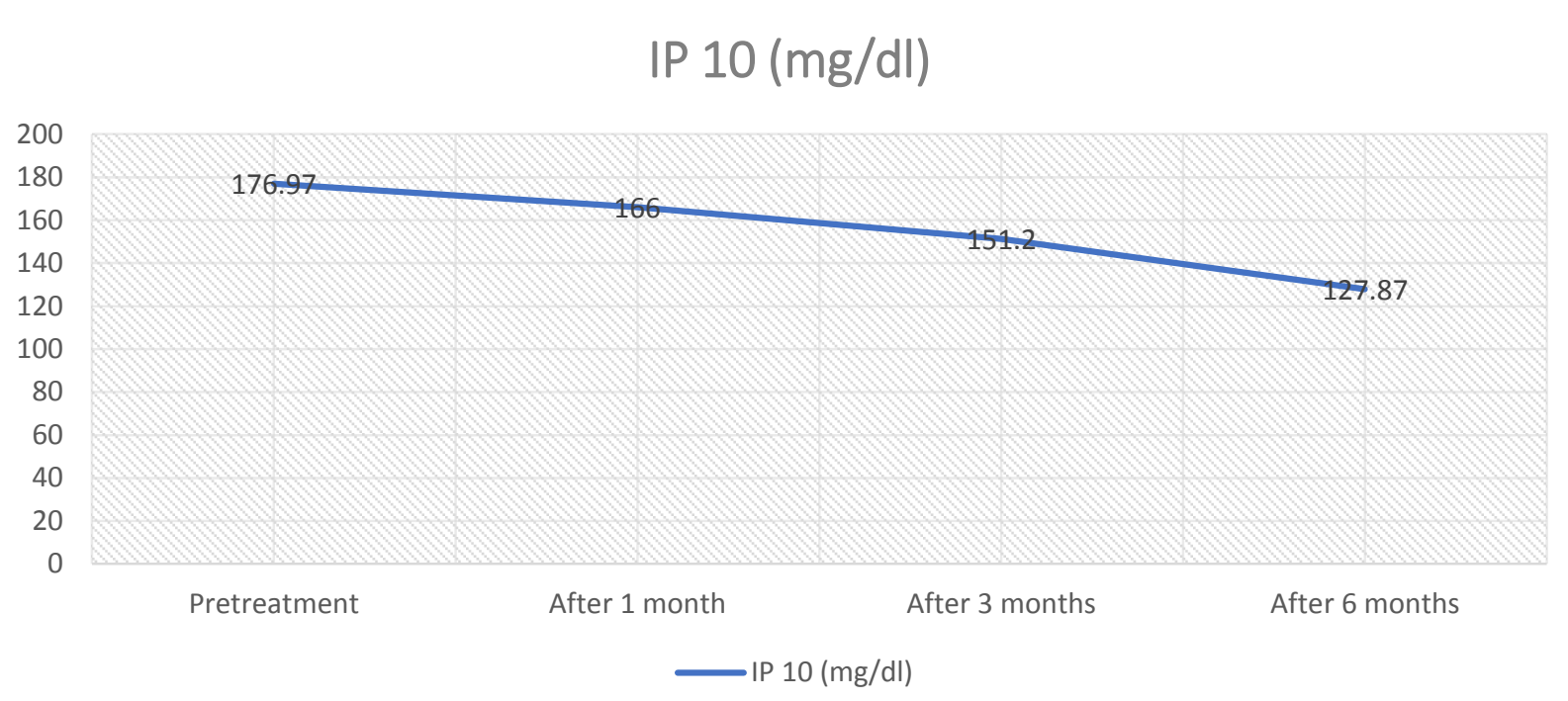

Figure (2): Effect of treatment with Sofosbuvir and Daclatasvir on IP10 serum level after 1, 3 and 6 months among the studied group of cases

Table (5) and figure (2) showed that direct acting antiviral therapy in the form of sofosbuvir and daclatasvir significantly influenced IP 10 serum level concentrations as pretreatment IP 10 serum level mean was $176.97 \pm 73.70$ $\mathrm{pg} / \mathrm{ml}$, then decreased to $166.0 \pm 69.3 \mathrm{pg} / \mathrm{ml}$ after 1 month of treatment, then became $151.2 \pm 60.9 \mathrm{pg} / \mathrm{ml}$ after 3 months (at the end of treatment). The lowest concentration of serum IP10 was after 3 months of the end of treatment $(127.87 \pm 52.8 \mathrm{pg} / \mathrm{ml})$. This serial change in concentrations was statistically highly significant $(\mathrm{P}$ value $<0.001)$.

Table (6): Effect of treatment with sofosbuvir and daclatasvir on serum HCV PCR level after 1, 3 and 6 months among the studied group of cases

\begin{tabular}{|c|c|c|c|c|c|c|c|}
\hline \multirow{2}{*}{$\begin{array}{c}\text { HCV PCR } \\
(\text { log IU/ml) }\end{array}$} & Pretreatment & $\begin{array}{c}\text { After 1 } \\
\text { month }\end{array}$ & $\begin{array}{c}\text { After 3 } \\
\text { months (at } \\
\text { the end of } \\
\text { treatment) }\end{array}$ & $\begin{array}{c}\text { After 6 } \\
\text { months }\end{array}$ & $\begin{array}{c}\text { Multivariate } \\
\text { Tests }\end{array}$ & $\begin{array}{c}\text { P } \\
\text { value }\end{array}$ & Sig. \\
\hline $\begin{array}{c}\text { Mean } \pm \text { SD } \\
\text { Range }\end{array}$ & $\begin{array}{c}39 \times 10^{4} \pm 78 \times 10^{4} \\
12 \times 10^{2}-4 \times 10^{6}\end{array}$ & 0.0 & 0.0 & 0.0 & 9.937 & 0.003 & $\mathrm{~S}$ \\
\hline
\end{tabular}

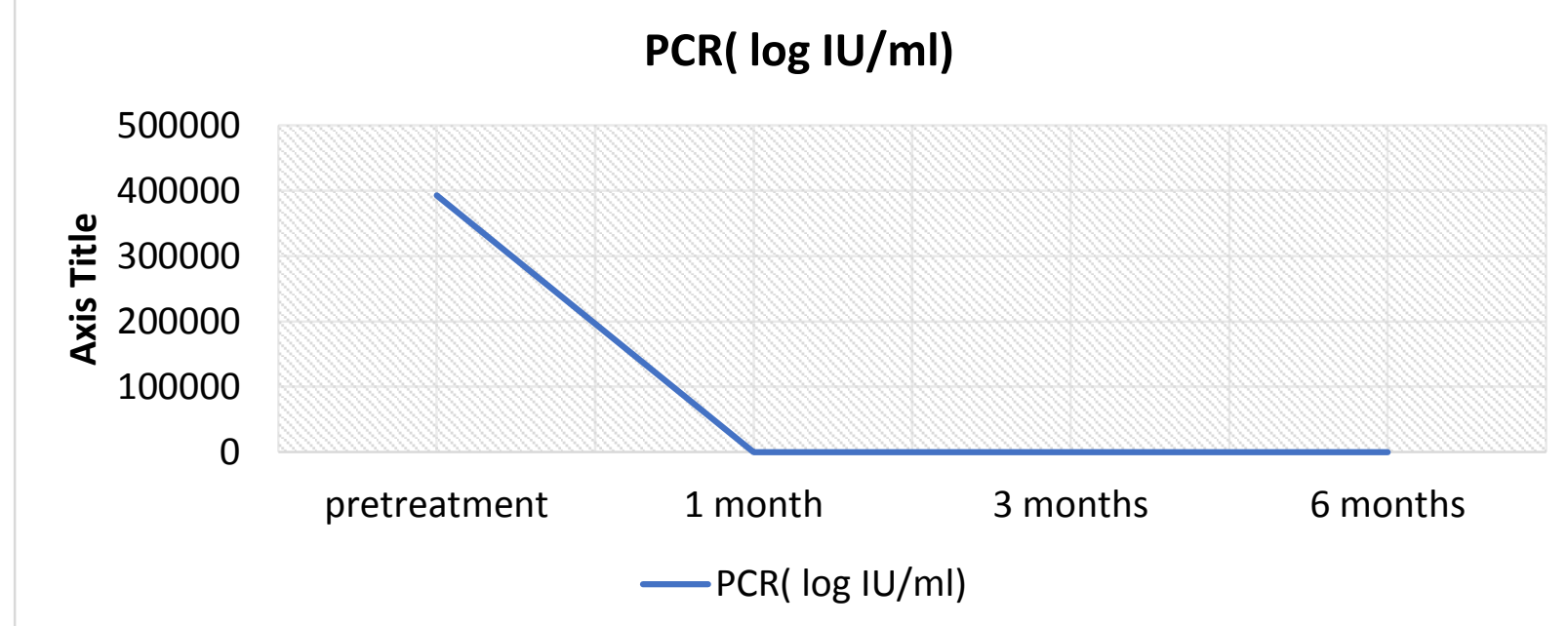

Figure (3): Effect of treatment with Sofosbuvir and Daclatasvir on serum HCV PCR level after 1, 3 and 6 months among the studied group of cases. 
Table (6) and figure (3) showed that direct acting antiviral therapy in the form of sofosbuvir and daclatasvir significantly influenced the load of viremia. HCV PCR mean was $39 \times 10^{4} \pm 78 \times 10^{4} \log$ $\mathrm{IU} / \mathrm{ml}$ before start of treatment, then declined to undetectable level after one month of treatment till 3 months after the end of treatment. This serial change in concentrations was statistically significant $(\mathrm{P}$ value $<$ 0.05). There was break through documented to one patient during treatment $\left(\mathrm{PCR} 1 \times 10^{4} \log \mathrm{IU} / \mathrm{ml}\right.$ ) and one relapse 3 months after end of treatment (PCR 1.4x $\left.10^{4} \log \mathrm{IU} / \mathrm{ml}\right)$.

\section{DISCUSSION}

Cases diagnosed as chronic hepatitis $\mathrm{C}$ virus (HCV) with or without cirrhosis by ELISA and PCR tests showing serum positive for $\mathrm{HCV}$ antibodies and RNA respectively in addition to age and sex matched apparently healthy subjects as control were the subjects of this study. Cases included 40 subjects (30 males and 10 females) while controls were 20 (11 males and 9 females). The 40 cases were classified according to hepatic echogenic pattern into 2 groups. 27 patients $(67.5 \%)$ with No cirrhosis, 13 patients $(32.5 \%)$ with cirrhosis. All patients were subjected for treatment with direct acting antiviral therapy (DAAT) in the form of oral sofosbuvir $400 \mathrm{mg}$ and daclatasvir $60 \mathrm{mg}$ daily \pm Ribavirin (in cirrhotic patients).

For 12 weeks. During treatment, they were closely monitored and followed up after 1 month of treatment, 3 months of treatment (at the end of therapy) and 3 months after the end of therapy by laboratory investigations including quantitative PCR for hepatitis C virus RNA, serum level of IP 10, direct and total bilirubin and serum creatinine.

In this study, the result of socio-demographic characteristics of the studied groups revealed that the mean age of $\mathrm{HCV}$ patients was $43.95 \pm 13.72$ years old and that of control group was $40.20 \pm 8.64$ years old with no significant difference. There was no significant difference between cases and control as regards comorbidities like smoking, hypertension and ischemic heart disease ( $\mathrm{P}$ value $<0.05)$. Also, there was no significant difference as regards residence. The result of this study agrees more or less with El Hendawya $\boldsymbol{e t}$ al. (7) who reported that in studied 27 hepatitis C patients (13 male and 14 female) with cirrhosis taking triple therapy (sofosbuvir, ribavirin, and interferon). The mean age of hepatitis $C$ patients was $49.19 \pm 11.50$ years and that of the control group was $42.93 \pm 12.88$ years.

The incidence of hepatitis $\mathrm{C}$ infection was higher in patients aged more than 45 years old, with no statistically significant difference $(P>0.05)$. Smoking was not a significant risk factor for liver cirrhosis $(\mathrm{P}>$ $0.05)$. No significant difference $(\mathrm{P}>0.05)$ was found between liver cirrhotic patients from rural areas and those coming from urban areas. Moreover, $30 \%$ of studied cases were hypertensive. Zhen-Qi et al. ${ }^{(8)}$ reported that 72 patients with chronic hepatitis $\mathrm{C}$ and 21 apparently healthy persons were enrolled in their study. As regard patients median age was 36 (18-52) years (50 males and 22 females) while controls median age was 30 (22-38) years (13 males and 8 females). They denoted that there was no significant difference between cases and controls as regards age and sex ( $\mathrm{P}$ value $>0.05$ ).

In this study, the result of comparison between studied groups as regards pretreatment IP10 serum level revealed that IP 10 serum concentrations were significantly higher in patients' $(176.97 \pm 73.70$ and median $149 \mathrm{pg} / \mathrm{ml}$ ) than in control group (mean $84.85 \pm 10.55$ and median $85.5 \mathrm{pg} / \mathrm{ml}$ ). Moallemi et al. (9) compared serum level of IP-10 between patient with chronic HCV and control group. In patients group serum level of IP $10(401.4 \pm 367.7 \mathrm{pg} / \mathrm{ml})$ was significantly higher than in the control group (70.8 \pm 24.2). Claudia et al. ${ }^{(10)}$ reported that IP-10 plasma levels (median $\mathrm{pg} / \mathrm{ml}$ and range) were higher in HCV monoinfected patients (393.8 and 58.7-568.5) in comparison with healthy donors (81.32 and 27.67236.32) ( $\mathrm{P}=0.0001)$. Johansson et al. ${ }^{(11)}$ in USA, reported that serum level of IP-10 was higher in HCV infected patients than healthy people. The results of our work are coincident to the aforementioned results.

In the present study, the result of comparison between studied groups as regards pretreatment IP10 serum level revealed that there was significant correlation between pretreatment IP 10 serum level and the degree of cirrhosis. Cirrhotic patients serum IP 10 concentrations levels (mean $218.53 \pm 77.38$ and median $192 \mathrm{pg} / \mathrm{ml}$ ) were higher than non-cirrhotic patients (mean $156.96 \pm 64.07$ and median $142 \mathrm{pg} / \mathrm{ml}$ ) serum IP 10 concentration levels ( $\mathrm{P}$ value $<0.05$ ). The result of this study agrees with the results of Zeremski et al. ${ }^{\left({ }^{(12)}\right)}$ who reported that IP-10 serum level correlate with $\mathrm{HCV}$-induced fibrosis being as an HCV related liver disease activity criterion.

Moallemi et $\boldsymbol{a l}{ }^{\left({ }^{(9)}\right.}$ in their study denoted that serum level of IP-10 in patient group with high level of liver enzymes, was higher than people with normal level of liver enzymes and if the fibrosis level was considered, they found stronger correlation between IP-10 and fibrosis level. While, The results of this work disagree with Masciaa et al. ${ }^{(10)}$ who reported that $\mathrm{HCV}$ monoinfected patients, after stratifying them according to the stage of liver fibrosis in mild fibrosis (F0-F2), severe fibrosis (F3) and advanced fibrosis (F4). IP-10 levels were higher in all groups when compared to healthy donors $(\mathrm{P}<0.0001 \mathrm{~F} 0-\mathrm{F} 2, \mathrm{~F} 3$ and F4 respectively vs. healthy donors), but they did not find differences among low, severe and advanced fibrosis groups. Also, Geórgia et al. ${ }^{(13)}$ reported that IP 10 serum pattern in chronic hepatitis $\mathrm{C}$ patients did not present any statistically significant findings according to the liver disease stage. The discrepancy between the aforementioned results may be attributed to the difference in choice of cases and the investigated 
procedures as the other studies depend on liver fibroscan while in this study patients classified according to abdominal ultrasound only.

In this study, the result of correlation between pretreatment IP 10 serum level and hepatitis $\mathrm{C}$ viral load in cases group showed that HCV PCR level and IP 10 serum level concentration, both were high but statistically not significant $(\mathrm{P}$ value $>0.05$ ). The result of this study agrees more or less with the results of Chan et al. ${ }^{\left({ }^{(14)}\right.}$ who reported that HCV-RNA titer did not correlate with serum IP-10 levels ( $\mathrm{r}=0.063$; $\mathrm{p}=0.579$ ). In addition, Zhang et al $^{\left({ }^{(15)}\right.}$ reported that IP10 levels at baseline were higher in patients with high virus loads $(476.17 \pm 38.88 \mathrm{pg} / \mathrm{mL})$ than in patients with low virus loads $(428.44 \pm 47.25 \mathrm{pg} / \mathrm{mL})$, but difference was not statistically significant. Also, El Hendawya $e t$ al. ${ }^{(7)}$ reported that concentrations of serum IP- 10 in $\mathrm{CHC}$ patients were positively correlated with the levels of serum HCV- RNA ( $\mathrm{r}=0.36, \mathrm{P}<0.001)$. While, Willemse et $\boldsymbol{a l} .{ }^{(16)}$ revealed that the concentrations of serum IP- 10 in $\mathrm{CHC}$ patients were positively correlated with the levels of serum HCV- RNA ( $r=$ $0.81, \mathrm{P}<0.0001)$.

In the present study, the result of effect of treatment with sofosbuvir and daclatasvir on IP10 serum level after 1, 3 and 6 months among cases denoted that direct acting antiviral therapy in the form of sofosbuvir and daclatasvir significantly influenced IP 10 serum level concentrations as pretreatment IP 10 serum level mean was $176.97 \pm 73.70 \mathrm{pg} / \mathrm{ml}$, then decreased to $166.0 \pm 69.3 \mathrm{pg} / \mathrm{ml}$ after 1 month of treatment, then became $151.2 \pm 60.9 \mathrm{pg} / \mathrm{ml}$ after 3 months (at the end of treatment). The lowest concentration of serum IP10 was after 3 months of the end of treatment $(127.87 \pm 52.8 \mathrm{pg} / \mathrm{ml})$. This serial change in concentrations was statistically highly significant $(\mathrm{P}$ value $<0.001)$.

The results of this study coincide with the results of Geórgia et al. ${ }^{(13)}$ who reported down regulation of immune mediators in chronic hepatitis $\mathrm{C}$ patients after DAA therapy. This pattern was statistically significant for chemokines CXCL-10 (IP 10) $\left(\mathrm{P}<0\right.$ 0001). Also, Masciaa et al. ${ }^{(17)}$ reported that in patients treated with IFN-free DAA regimens, there was a marked decrease of CXCL10 (IP 10) plasma levels at T1 (after 4 weeks of therapy) and its values remained low up to SVR12 (T2:12 weeks after the end of treatment $)(\mathrm{p}<0.0001)$.

In this study, the result of effect of treatment with sofosbuvir and daclatasvir on serum HCV PCR level after 1, 3 and 6 months among cases revealed that direct acting antiviral therapy in the form of sofosbuvir and daclatasvir significantly influenced the load of viremia. HCV PCR mean was $39 \times 10^{4} \pm 78 \times 10^{4} \log$ $\mathrm{IU} / \mathrm{ml}$ before start of treatment, then declined to undetectable level after one month of treatment till 3 months after the end of treatment. This serial change in concentrations was statistically significant $(\mathrm{P}$ value $<$ 0.05). The results of this study are in agreement with the results of Stanislas et al. ${ }^{(18)}$ who reported that sofosbuvir + daclatasvir combination is associated with a high rate $(95 \%)$ of viral eradication in patients. $\mathrm{T}$

he best duration of a ribavirin-free sofosbuvir + daclatasvir combination seemed to be 12 weeks in noncirrhotic patients and 24 weeks for those with cirrhosis. Besides, Yang and Kao ${ }^{(19)}$ reported that patients with chronic HCV infection treated with a combination of sofosbuvir and daclatasvir demonstrated an SVR of 94-100\%.

In this study, there was 31 years old male relapser patient with hepatosplenomegaly, Child Pugh score class A had undetectable viral load at the end of antiviral therapy then presented detectable HCV-RNA $\left(1.4 \times 10^{4} \log \mathrm{IU} / \mathrm{mL}\right) 12$ weeks after the end of treatment.

Another female breakthrough patient 43 years old Child Pugh score class A with mild thrombocytopenia, alpha feto protein $29 \mathrm{ng} / \mathrm{mL}$ had undetectable viral load after 1 month of treatment then presented with detectable HCV-RNA ( $1 \times 10^{4}$ log $\mathrm{IU} / \mathrm{mL}$ ) at the end of treatment. This result agrees more or less with Geórgia et al. ${ }^{(13)}$ who reported that only one patient that had undetectable viral load $(<25$ $\mathrm{IU} / \mathrm{mL}$ ) at the end of antiviral therapy, presented with detectable HCV-RNA (765 IU/mL) 12 weeks after the end of treatment, being characterized as a relapse patient.

This individual was a 45-year-old female, infected by HCV, with decompensated cirrhosis. Furthermore, this patient presented a clinical history of hypertension, dyslipidemia, hypothyroidism, and diabetes mellitus with notification of chronic venous leg ulcer.

\section{CONCLUSIONS AND RECOMMENDATIONS}

IP 10 may be used as a prognostic marker for treatment efficacy in chronic HCV infected patients subjected to DAAs in the form of sofosbuvir/daclatasvir combination, which is associated with a high rate of SVR in patients who are assumed to be difficult to treat. Adding ribavirin increased the SVR rate in cirrhotic patients. IP 10 serum level concentrations significantly influenced under effect of aforementioned management in a descending manner proved by IP 10 serum level follow up within and after treatment.

Although IP 10 serum level proved to be positively correlated with the degree of liver cirrhosis, however its increase in serum level is not specific for $\mathrm{HCV}$ infection as it may increase in many conditions like inflammatory bowel disease, primary biliary cirrhosis, recent pregnancy, DiGeorge syndrome and neuromyelitis optica. However, in comparison with PCR test as regard HCV infection diagnosis it was clear that PCR test for HCV RNA still the standard confirmatory diagnostic test for HCV infection. 
From this study we can recommend that further research on more wide scale is recommended to clearly evaluate the correlation between IP 10 serum level and the degree of liver cirrhosis secondary to $\mathrm{HCV}$ infection using more advanced diagnostic tools like combination of Fibro-Meter ${ }^{\circledR}$ and Fibro-Scan ${ }^{\circledR}$. Using more than biomarker beside IP 10 and studying their dynamic changes in $\mathrm{HCV}$ infection and management may increase the specificity of these markers together in diagnosis and follow up in $\mathrm{HCV}$ infected patients.

\section{REFERENCES}

1. Brett D, Lindenbach H, Charles M (2007): Rice Fields Virology - Flaviviridae: The Viruses and Their Replication, D.M.K.a.P.M. Howley, Editor, Eds. Lippincott-Raven Publishers: Philadelphia. Pp: 11021103.

2. Abd Elrazek AE, Bilasy SE, Elbanna AE (2014): Prior to the oral therapy, what do we know about HCV-4 in Egypt: a randomized survey of prevalence and risks using data mining computed analysis. Medicine (Baltimore), 93: 204-9.

3. Zeremski M (2008): Intrahepatic Levels of CXCR3-associated Chemokines correlate with liver inflammation and fibrosis in chronic hepatitis C. Hepatology, 48 (5): 1440- 50.

4. Roe B, Coughlan S, Hassan et al. (2007): Elevated serum levels of interferon- gamma -inducible protein-10 in patients coinfected with hepatitis $\mathrm{C}$ virus and HIV. J Infect Dis., 196: 1053-7.

5. Lagging M, Romero AI, Westin J et al. (2006): DITTOHCV study group. IP-10 predicts viral response and therapeutic outcome in difficult-to-treat patients with HCV genotype 1 infection. Hepatology, 44: 1617-25.

6. Abd-Elsalam S, Sharaf-Eldin M, Soliman S et al. (2017): Efficacy and safety of sofosbuvir plus ribavirin for treatment of cirrhotic patients with genotype 4 hepatitis $\mathrm{C}$ virus in real-life clinical practice. Archives of Virology, 3: 1-6.

7. El-Hendawya GR, Salamaa AA, Elshaybb EI et al. (2017): Study of interferon- $\gamma$-inducible protein-10 levels during antiviral therapy of hepatitis $\mathrm{C}$ patients with sofosbuvir plus ribavirin and interferon in Menoufia hospitals. Menoufia Medical Journal, 30: 997-1004.

8. Zhen-Qi H, Huang T, Yong-Zhi D et al. (2015): Expression profile and kinetics of cytokines and chemokines in patients with chronic hepatitis C, Int J Clin Exp Med., 8 (10): 17995-18003.

9. Moallemi Z, Ayatollahi J, Dosti M (2015): Serum and Urine Level of IP-10 in Patients with HCV infection
Based on Clinical and Virological Markers. Iranian Journal of Virology, 9 (4): 1-8.

10. Masciaa $C$, Lichtnera $M$, Zuccalàa $P$ et al. (2017): Active $\mathrm{HCV}$ infection is associated with increased circulating levels of interferon-gamma inducible protein10 (IP-10), soluble CD163 and inflammatory monocytes regardless of liver fibrosis and HIV coinfection. Clin Res Hepatol Gastroenterol., 41 (6): 644-655.

11. Johansson S, Talloen W, Tuefferd $M$ et al. (2015): Plasma levels of growthrelated oncogene (CXCL1-3) associated with fibrosis and platelet counts in $\mathrm{HCV}$ infected patients. Aliment Pharmacol Ther., 42 (9): 1111 21.

12. Zeremski M, Dimova R, Astemborski J et al. (2011): CXCL9 and CXCL10 chemokines as predictors of liver fibrosis in a cohort of primarily African American injection drug users with chronic hepatitis C. Journal of Infectious Diseases, 204 (6): 832-6.

13. Geórgia NS, Natalia FR, Thalia M et al. (2018): Restoring Inflammatory Mediator Balance after Sofosbuvir- Induced Viral Clearance in Patients with Chronic Hepatitis C. https://www.hindawi.com/journals/mi/2018/8578051/

14. Chan RY, Park SH, Jeong SW et al. (2011): Serum IP10 Levels Correlate with the Severity of Liver Histopathology in Patients Infected with Genotype-1 HCV. Gut and Liver, 5 (4): 506-512.

15. Zhang R, Shao C, Huo N et al. (2016): Association of IL28B Genotypes and Baseline Serum Interferon- $\gamma$ Inducible-Protein-10 Levels with Treatment Response in Hepatitis C Virus Patients in China. Gut and Liver, 10 (3): 446-455.

16. Willemse SB, Reesink HW, Ladee K et al. (2014): IP-10 in chronic hepatitis C patients treated with high-dose interferon. Neth J Med., 72: 407-415.

17. Masciaa $C$, Vita $S$, Zuccalà $P$ et al. (2017): Changes in inflammatory biomarkers in $\mathrm{HCV}$ infected patients undergoing direct acting antiviral-containing regimens with or without interferon, https://doi.org/10.1371/journal.pone.0179400 June 21.

18. Stanislas P, Marc B, Sandy L et al. (2016): Safety and efficacy of daclatasvir-sofosbuvir in HCV genotype 1mono-infected patients, Journal of Hepatology. https://www.researchgate.net/publication/308041511_Sa fety_and_efficacy_of_daclatasvirsofosbuvir_in_HCV_genotype_1-monoinfected_patients.

19. Yang SS, Kao JH (2016): Daclatasvir-containing all-oral regimens for the treatment of hepatitis $\mathrm{C}$ virus infection. Hepatol Int., 10: 258-66. 